CHRISTY EMILIO IOANNIDOU

The Association of Historical Studies

KORYVANTES

Athens, Greece

E-mail: perialos1@gmail.com
Received: November $14^{\text {th }} 2020$

Accepted: December $10^{\text {th }} 2020$

Original research article

904:355.48(38)"-04/-03"(044)

COBISS.SR-ID 29181449

https://doi.org/10.18485/arhe_apn.2020.16.2

\title{
LETTERS CAPTURED OR LOST DURING MILITARY OPERATIONS IN CLASSICAL GREECE (FIFTH TO FOURTH CENTURIES BC)
}

\begin{abstract}
In many cases, letters, which were sent between opponents during military operations in ancient Greece, have never reached their addresses. Some of them were lost and others were captured by enemies. This could have happened before, during, or at the end of a war conflict. Whatever the time, cases of lost or captured documents were an important factor for the subsequent attitude of belligerents.

\section{KEYWORDS: ANCIENT GREEK LETTERS, ANCIENT GREEK WARFARE, ANCIENT DOCUMENTS DURING WAR.}

The task of information transmission during military operations in Classical Greece demanded special attention. Generally, information transmission was obtained either through letters or orally. Often, systems of collecting data were the function of people that were not trained for these activities (merchants, actors, singers, doctors etc). These people generally supported low-grade information and they could easily channel misleading material (Ioannidou 2010: 22-29; Gerolymatos 2011: 30) but in some cases they could be examples of important military data which they picked up during travels (Russel 2002: 92).

Ensuring adequate, safe, and effective means of conveying information, as well as its secrecy was totally dependent on sending trusted people. These people were ready, if needed, to pass through dangerous situations in order to reach their destination and deliver their documents. Usually the sender and recipient had previously agreed, somehow, for a system to be followed (Aen. Tact. $31,31)$. When the message was written in a letter, then the correspondents often followed the deposit method by dropping it off at some mutually agreed point . The recipient was notified through a third person that appeared e.g. in town to buy or sell something. The letter was delivered to the known location by that third person.

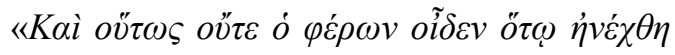

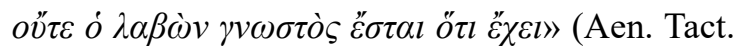
31.31.4). [In this way the messenger did not know to whom the letter was finally brought, nor would it be known whether the recipient had actually received it.]

For keeping confidentiality, the transmission of information utilised ingenious tricks, which often served as alternative ways of communication so as to reduce potential enemy interception, and offered valuable services (Ioannidou 2010: 22-29; 2016: 108-115).

Aeneas Tacticus (fourth c. BC) advised that written messages could, among other things, be forwarded written on tin and sewn into the soles of the messenger's shoes, written on tree leaves 
tied with a bandage over a wound that the messenger had on his foot, or, again, written on the bridle of a horse, or even in thin, wrapped lead sheets that women wore on their ears instead of earrings. Furthermore, reference is made to the usage of courier dogs:

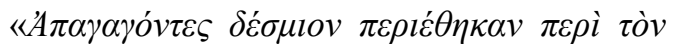

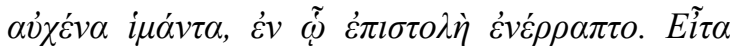

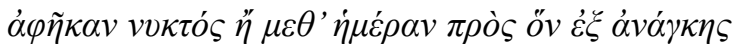

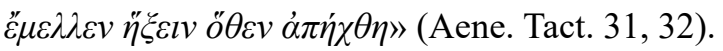

[... and fasted round their necks a strap in which a letter was sewn. Then, either by night or by day, they let them go and find their way home, which they were sure to do].

But, despite the efforts to secure transmission of information, there were cases where messengers were captured. If the information was oral (memorized by the messanger) ${ }^{1}$ then maybe it would never come out from the captured messenger, even if he knew that he might die. If was written in a letter, then the valuable documents passed immediately to the foe's hands as Captured Enemy Documents (CED).

CED are the most reliable source of information and can provide vital data about the enemy's plans, the state of his condition, his combat worthiness, his order of battle, tactics, methods, codes etc. (Ioannidou 2016: 111)

The best-known CED in classical texts is the letter that the Lacedaemonians sent after their defeat and the loss of their admiral Mindarus in the naval battle of Cyzicus (410 BC). This letter, well known for its laconic style, never reached the Lacedaemon because they had fallen to the Athenians:

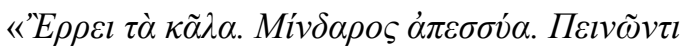

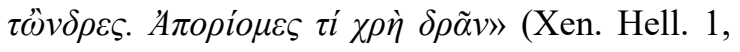
$1,23)$.

[The ships are gone. Mindarus is dead. The men are starving. We know not what to do].

During the winter of $425 \mathrm{BC}$ the Athenians captured the Persian Artaphernes, who was traveling to Lacedaemon as an envoy of the High King. Artaphernes was going to deliver letters from the

1 Among others, see Arrian, Alexander Anabasis, 1, 25.
High King to the Spartans. The letters, written in Assyrian characters, were captured by the Athenians; they translated them and revealed, inter alia, the relations between Sparta and Persia. Persia had not understood what the Spartans wanted from them so they asked the Spartans to be more specific and to send their ambassadors accompanied by Artaphernes. ${ }^{2}$

The following trick, applied by a general from Skione, ${ }^{3}$ Timoxenos, and the Persian Artabazus, ${ }^{4}$ is also interesting. Timoxenos agreed with Artabazus to deliver to him Poteidaia by betrayal. After they had first planned to designate two specific points, one in the city and one in the camp, they sent their messages by using bows. They wrote their text on a papyrus piece and wound it around the notches of the arrow. We might never have learned about this plot if Artabazus had not missed his shot. It is said that because of the wind direction and the misapplication of the arrow wings he wounded a Poteidaian soldier by accident.

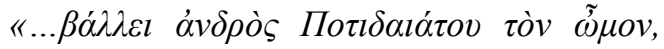

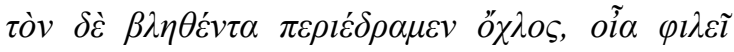

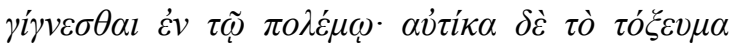

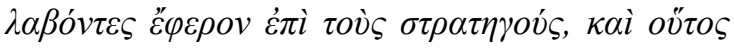

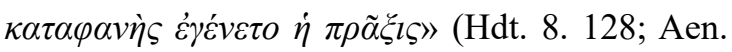
Tact. 31.25).

[... and hit a Potidaean in the shoulder. As often happens in war, a crowd ran up to the wounded man: and they at once seized the arrow and took it to the generals, so that the plot was discovered].

The Spartan admiral Lysander sent letters to Pausanias, who was based at Plataea (395 BC). Through these letters he notified him that, among other things, he had to meet him at Haliartos (Boeotia). The letters never arrived at their des-

2 After this apocalypse, the Athenians sent their ambassadors, accompanied by Artaphernes, who sailed with a trireme to Ephesus in order to renew the truce between Athens and Persia. Upon arrival they learned about the death of King Artaxerxes and returned to Athens. Thucydides, History of the Peloponnesian War, 4, 50.

3 Ancient Greek city in Pallene, the westernmost headland of Chalcidice.

4 Artabazus I (480 BC - 455 BC) was a satrap of Hellespontine Phrygia (now northwest Turkey). 
tination. On the contrary, they were received as CED by the Thebans because the courier was captured in a spying ambush (Plut. Lys. 28).

The importance of CED, however, can be used for the benefit of those who lost them on purpose. If a letter of paramount importance deliberately reaches the enemy's hands, then he, believing that he owns CED, will not proceed to evaluate the information but will accept it as reliable (Ioannidou 2010: 22; 2016: 108-115).

We can derive a relevant example from Polyainus, which refers to the Macedonian King Philip, father of Alexander the Great. At the time, Philip was campaigning against Amphissa (338 $\mathrm{BC})$; the Athenians and Thebans had occupied the straights of Thermopylae beforehand in order to make them impregnable. Philip sent a fake letter to Antipatrus in Macedonia, saying that he had postponed the campaign and that he was supposedly hastening to Thrace because of an insurrection that had broken out there. When the messenger carrying the letter passed near the straights, the Athenian generals arrested him, read the message and without making an evaluation or verification of the information, having confidence that they possessed a reliable source, they abandoned their strong positions. Philip passed through the unguarded passage, defeated the enemy generals who had pulled out, and thus conquered Amphissa (Polyaenus 4. 2. 8).

The trick of making fake letters was quite frequent in ancient times. For example, Alexander the Great, when in Yrkania, ${ }^{5}$ wanted to know who from his immediate environment was saying good words about him and who was not. He told his men to write letters to their families, as he would, too. When the senders had made a distance of 3 posting stations, ${ }^{6}$ Alexander ordered them to come

5 Satrapy of ancient Persia, located in the territories of the present day Gilan, Mazandaran and Golestan provinces of Iran and part of Turkmenistan.

6 Stations of the Royal Road, an ancient highway rebuild by the Persian King Darious the Great (Darius I), in the 5 th century $\mathrm{BC}$. This route, having hundreds of posting stations, was used by couriers to deliver messages to the Persian capital. back. He opened the letters and learned the beliefs of his men (Polyaenus, 4. 3. 19; Diod. 17. 80).

Those who failed to accept or read their letters in time proceeded to misinterpretation of the information, while others suffered the negative outcome of a battle or even fell victim to murder.

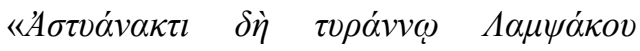

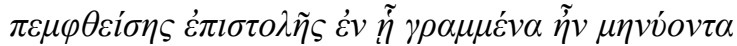

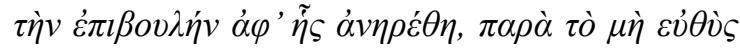

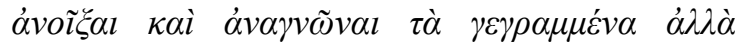

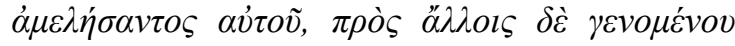

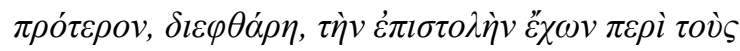
$\delta \alpha \kappa \tau \dot{\lambda} \lambda o v \varsigma »$ (Aen. Tact. 31. 34).

[A letter was sent to Astyanax, tyrant of Lampsacus, containing information of the plot which proved fatal to him: since, however, he did not open it at once and read the contents, but took no notice and attended to other business first, he was murdered with the letter unopened in his fingers].

In History there are cases where the message inadvertently got lost and never reached its destination. Plenty of them remain unknown in history. Some are testified to by others. Such a story is told by Plutarch about Timokrates (Plut. Dio. 26. 7. 10), who in his backpack had a letter that was to be delivered to Dionysius of Syracuse. During the journey, he slept overnight in a forest at the edge of the road. In his backpack he had a piece of meat, whose smell attracted a wolf. The wolf, in his attempt to grab the meat, took the backpack together with it. When Timokrates woke up and realized what had happened, he wandered a long time searching for the backpack, until he decided that it was better for him to disappear.

The importance of collecting and transmitting information was great from the most ancient times, since it would have had crucial importance in decisions and designs which in turn would furnish an adequate assessment of the situation i.e. the basis for Operational Planning. Lost or captured documents made their own factor in military history. Some of them could affect the outcome of a battle. From the texts of ancient writers we derive really surprising information that calls for 
further study and research, making this sector extremely fascinating.

\section{BIBLIOGRAPHY}

\section{Ancient}

Aeneas Tacticus, Poliorcetica

Diodorus, Historical Library

Herodotus, Histories

Plutarch, Dion

Plutarch, Lysander

Polyaenus, Strategems

Xenophon, Hellenica

\section{Contemporary}

Adcock, Sir Frank and D.J. Mosley, 1975.

Diplomacy in Ancient Greece, London.

\section{Gerolymatos, A. 1986}

Espionage and treason: A study of Proxenia in Political and Military Intelligence Gathering in Classical Greece, Amsterdam.

\section{Gerolymatos, A. 2011}

Espionage in Ancient Greece, [in Greek], Athens: Cactus Publications.

\section{Ioannidou, C.E. 2010}

Collecting \& transmitting information during the conduct of military operations in ancient Greece, [in Greek], Armies \& Tactics 2: 22-29.

Ioannidou, C. E. 2016

Trireme. Tactics and Operational Environment in

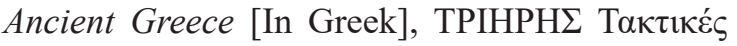

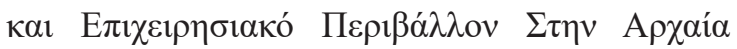
E $\lambda \lambda \alpha \dot{\alpha} \delta \alpha$, Athens: Naval History Department/Hellenic Navy.

Russel, F.S. 2002

Information Gathering in Classical Greece, Ann Arbor, The University of Michigan Press.
Starr, C.G., 1974.

Political Intelligence in Classical Greece, Leiden.

\section{REZIME}

PISMA KOJA SU BILA

ZAROBLJENA ILI IZGUBLJENA TOKOM VOJNIH OPERACIJA U KLASIČNOJ GRČKOJ (V-IV VEK PRE N. E.)

\section{KLJUČNE REČI: ANTIČKA GRČKA, PISMA, ANTIČKI GRČKI ORUŽANI SUKOBI, ANTIČKA DOKUMENTA TOKOM RATA.}

U mnogim slučajevima se dešavalo da pisma koja su učesnici u ratnim sukobima slali tokom ratnih operacija u antičkoj Grčkoj nikada ne stignu do svojih primalaca. Neka od njih su bila izgubljena, dok su druga pala u ruke neprijateljima. Ovo je moglo da se desi pre, tokom ili na kraju ratnog sukoba. U kojem god trenutku da se to dešavalo, slučajevi izgubljenih ili zarobljenih dokumenata bili su bitan činilac za budući odnos zaraćenih strana.

Arheologija i prirodne nauke (Archaeology and Science) is an Open Access Journal. All articles can be downloaded free of charge and used in accordance with the licence Creative Commons - Attribution-NonCommercial-NoDerivs 3.0 Serbia (https://creativecommons.org/licenses/ by-nc-nd/3.0/rs/.

Časopis Arheologija i prirodne nauke je dostupan u režimu otvorenog pristupa. Članci objavljeni u časopisu mogu se besplatno preuzeti sa sajta i koristiti u skladu sa licencom Creative Commons - Autorstvo-Nekomercijalno-Bez prerada 3.0 Srbija (https://creativecommons.org/ licenses/by-nc-nd/3.0/rs/. 